УДК $737: 398.4$ (56) «652»

DOI: https://doi.org/10.33782/eminak2021.1(33).507

\title{
УОСОБЛЕННЯ РІЧКОВИХ БОГІВ У МОНЕТНОМУ КАРБУВАННІ РИМСЬКОЇ ПРОВІНЦІЇ АЗІЯ
}

\author{
Анастасія Баукова \\ Львівський національний університет імені Івана Франка (Львів, Україна) \\ e-mail: anastasia_bau@ukr.net \\ ORCID: https://orcid.org/0000-0002-1636-981X
}

\begin{abstract}
Чудовим джерелом до вивчення різних аспектів історії та культури античності $\epsilon$ монети. У статті аналізуються персоніфікації річкових богів-уособлень головних річок заходу Малої Азї̈. Вони були транспортними артеріями, джерелом постачання питної води та продуктів харчування, природними кордонами між областями Малої Азії.

Монетне карбування із персоніфікаціями дає змогу відтворити гідрографічну ситуацію у регіоні, адже на теперішній час частина водних артерій змінила своє русло чи взагалі зникла. Також піднято питання про потребу перегляду певних трактувань символів. Встановлено, що у провінції доволі швидко сформувався уніфікований спосіб персоніфікації річкових богів, але особливого поширення у монетному карбуванні міст провінції припав на другу половину II - першу половину III cm. н.е. Аналіз легенд дозволяє також виділити певні епітети та локальні особливості загальногрецьких божеств.
\end{abstract}

Ключові слова: персоніфікація, річкові боги, римська провінція Азія, монетне карбування

Антична нумізматика є чудовим джерелом для вивчення історії та культури міст Середземномор'я. Аналіз типів оздоблення поверхні монет дає змогу прослідкувати значимі для місцевого населення образи та релігійно-філософські уявлення. Дуже часто на монетах різних полісів з'являлись зображення культових споруд, або головних богів регіону. Серед таких зображень важливе місце посідають зображення річкових богів. Ріки, у будь-який час існування людства, були важливим елементом повсякденного життя. Наявність доброго джерела питної води та заплавних терас було визначальним фактором для існування довготривалого поселення. Окрім того, річки відігравали важливу транспортну роль і виконували роль кордонів між історичними областями, державами та племенами. Усі ці фактори не могли не знайти відбиття у грецькій міфології, а через неї й у різних галузях візуальних практик античності. У вивченні монетного карбування та персоніфікацій божеств важливу роль відіграли дослідження Ф.ІмговБлюмера 1 , П. Ковалєвского ${ }^{2}$, С. Креміді-Сициліано 3 тощо.

Монетне карбування стало одним із способів зафіксувати значення річок у житті того чи іншого полісу. Прикладом є навіть монетне карбування Ольвії, ко-

\footnotetext{
${ }^{1}$ Imhoof-Blumer F. Fluss und Meergötter auf griechischen und römischen Münzen (Personifikationen der Gewässer). URL: https://ru.scribd.com/document/78787457/Fluss-und-Meergotter-aufgriechischen-und-romischen-Munzen-Personifikationen-der-Gewasser-von-Friedrich-Imhoof-Blumer ${ }^{2}$ Kowalewski P. Flussgötter und ihre Attribute auf antiken Münzen // Wiplinger G. Cura Aquarum in Ephesus. Leuven: Peeters, 2006. P. 3-16.

3 Kremydi-Siciliano S. «Belonging» to Rome, «remaining» Greek: coinage and identity in Roman Macedonia. URL: https://core.ac.uk/download/pdf/61193493.pdf
} 
ли зображення бородатої персоніфікації Борисфена прикрашало бронзові оболи IV-III ст. до н.е. Монети з таким оздобленням були масовими і це робило їх часто використовуваним платіжним засобом, а отже ідентифікація річки та поширення цього символу було досить впізнаваним і тиражованим. П.О. Каришковський виділив 17 видів таких монет ${ }^{4}$. У сучасній масовій культурі для позначення такого типу монет так і закріпилась назва «борисфени», хоча паралельно використовується й назва «ольвійський обол». Цікаво $є$ те, що під тиском зовнішніх обставин чи розвитку добробуту регіону зображення річкових богів зазнавало певних змін. Саме тому у запропонованому дослідженні йтиметься про образ річкових богів у монетному карбуванні міст римської провінції Азія. Цей регіон і його монетне карбування дає змогу прослідкувати зміни в ідеології та культурі населення типового грецького міста під впливом включення до складу римської держави та поступової й потужної романізації. Накладення двох культурних традицій під тиском політичних обставин і $є$ в центрі уваги даного дослідження.

Річкові боги в античній міфології були чисельними дітьми титанів Океану та Тефіди (Тефії). Загалом було відомо про 3000 річок і 4000 океанід, які народились від цього шлюбу. Показним є той факт, що з 25 річок-синів Тефіди та Океану, перерахованих у «Теогонії» Гесіода5 ${ }^{5}$ вісім протікали в Анатолії і на території римської провінції Азія зокрема. Взагалі, річковий бог вважався годувальником країни, його вшановували різноманітними вівтарями та присвячували гаї. Часто річкового бога вважали міфічним царем країни. До прикладу можна згадати Кінаха в Аргосі чи Скамандр у Троаді. Великі, значущі річки зображували у вигляді старшого за віком чоловіка з тростиною. Річки поменше чи потічки візуалізували у вигляді молодого чоловіка з квіткою у руці. Безсумнівно, що значення річки у житті регіону підкреслював ріг достатку в руці зображення відповідного бога.

Також, у випадку Причорномор'я чи материкової Греції, річкових богів зображали у вигляді бика, рев якого міг здалеку нагадувати рев бурхливого потоку. До монетних штампів перенесена й антична традиція зображати річкового бога лежачим, спертим на урну, з якої витікає вода. Хоча для римської держави, у форматі республіки та імперії, головними річками за історичним значенням були Тибр і Ніл, однак саме малоазійські та східні провінції дали найбільше зразків персоніфікацій річкових богів. Цікаво, що постаті річкових богів з'являються у карбуванні часів Октавіана Августа на монетах Антіохії над Оронтом, у Сирії і, по тому, подібні штампи використовувались у карбуванні провінції Азія.

Провінція Азія, утворена після заповіту останнього Атталіда на території Пергамського царства у 133 р. до н.е., була по суті не монолітним утворенням, а об'єднанням великої кількості полісів. Одним із наслідків включення до складу римської держави стало збереження місцевого карбування, адже його завданням було насичення добре сформованого місцевого ринку платіжними засобами, передусім дрібних номіналів. Проаналізовані монети із зображенням річкових богів дозволяють наголосити на кількох важливих аспектах.

Гідрографічна ситуація на західному узбережжі Малої Азії визначалася наявністю у регіоні кількох великих річок. Передусім йдеться про Герм (Gediz Nehri, `Е $\rho$ ољ, Hermos (Hermus)) і Меандр (Büyük Menderez, Meandros) - дві найбільші

\footnotetext{
${ }^{4}$ Каришковский П.О. Монеты Ольвии: Очерк денежного обращения Семеро-Западного Причорноморья в античную епоху. Киев, 1988. С. 101.

5 Гесиод, Теогония, 340.
} 
ріки. Усі річки регіону були важливими водними транспортними артеріями та виконували роль природних кордонів між історичними областями племен і царств. На відміну від річок басейну Чорного моря, ріки на території провінції Азія впадали здебільшого в Егейське, Мармурове та Середземне море. Не маючи великого судноплавного значення, тим не менше усі річки провінції були важливими джерелами постачання води для споживання та зрошення, а також це було середовище для багатої флори і фауни.

Герм відділяв Еолію від Іонії (разом з Іонійською Фокеєю на півночі), Риндак був кордоном між Місією та Віфінією, Меандр розділяв Карію та Лідію. 3 більшістю з цих річок, відповідно до цих особливостей, були пов'язані важливі історичні битви.

Найбільшою та найважливішою річкою Карії була без сумніву ріка Меандр

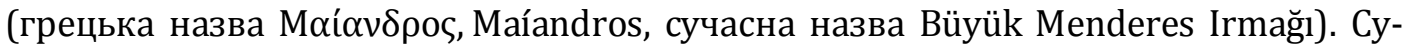
часна площа його басейну складає 25000 кв. км. Ще у давнину точилися дискусії щодо витоків Меандра та його приток, зокрема Марсія. Про мешканців долини Меандру згадується у «Каталозі кораблів» в «Іліаді» (Іліада, II, 865). Звивисте русло ріки та його притоки Марсія дало назву орнаменту та явищу утворення руслових форм побідної форми - меандрування. Меандр був не широким, але глибоким. Меандр витікає в Келенах у Фригії, пливе до заходу, приймаючи притоки Марсій, Гарпас і Лік, протікає по правому боку гори Месогіса та впадає до Ікарського моря між Міунтом і Прієною. У досліджуваний час Меандр часто спричиняв повені та наносив намул. Овідій називає його таким, що «тече і туди, і назад» (Овідій, Метаморфози, IX, 450) Тим не менше, річка відігравала надзвичайно важливу роль, що не могло не призвести до пошанування бога Меандра. Про його епіклезу й особливості культу відомо мало. Ймовірно, це стало наслідком того, що карійців греки здавна вважали варварами. Дітьми Меандра називали Кіанею, матір Бібліди і Кавна 6 , Самію, дружину царя лелегів Анкея7, Каламоса, який став тростиною ${ }^{8}$ та Каллірої.

Монети із персоніфікацією річкового бога Меандра карбувались у багатьох містах, розташованих у басейні ріки. Передусім варто згадати Аполлонію-Тріполіс, Прієну, Антіохію, Тралли тощо. Цікавим феноменом $є$ те, що на монетах Магнезії над Меандром в Іонії річковий бог Меандр з'являвся вкрай рідко.

Найбільш чисельними з досліджених зразків персоніфікації Меандра на монетах $€$ карбування міста Тріполіс. Загалом з цим об'єктом є кілька проблем із локалізацією та назвою, адже у різних античних джерелах поліс фігурує не тільки під іншими назвами, але й локалізується у межах різних областей. Наприклад, Пліній Старший говорить про Тріполі як про лідійське місто, а Птоломей і Стефан Візантійський - як про карійське. Це пояснюється тим, що населений пункт був розташований на кордоні Фрігії, Карії та Лідії на північному березі верхньої течії Меандра, на шляху від Сард до Філадельфії та Лаодикеї над Ліком. У нумізматичних каталогах також немає одностайності у місці локалізації Тріполісу. В різний час місто мало назву Трі́то $\iota \varsigma$, Tripolis, Apollonia (Aто $\lambda \lambda \omega v i ́ \alpha)$, Antoniopolis, Tripolis ad Maeandrum.

Слід відзначити, що Тріполіс, на відміну від більшості міст провінції Азія, досягнув свого розвитку власне у римський час, приблизно у II ст. н.е. Це позначається

\footnotetext{
6 Овідій, Метаморфози, IX, 450.

7 Павсаній, Опис Еллади, VII, 4.1.

8 Nonnos, Dionysiaka 11, 370-481.
} 
на збільшенні монетного карбування та різноманітності типів оздоблення. Постать річкового бога Меандра показана на монетах Тріполіса у вигляді старшого чоловіка, який лежить на лівому боці, тримаючи тростину та ріг достатку. Ліва рука спирається на перевернуту урну. Саме таке зображення для зручності пропонується називати «канонічним». Згодом цей образ може мати різні варіації, але важливо підкреслити наступне: наявність води, що витікає з амфори (урни) чи іншої посудини сучасним дослідником П. Ковалевським (Peter Kowalewski) трактується як фіксація на час карбування факту існування водогону (акведуку) у місті-емітенті. Таке зауваження $є$ дуже важливим з огляду на меморативність карбування римського часу та вивчення системи водопостачання через нумізматичні джерела. Однак проведений аналіз монетного матеріалу, наприклад карбування Магнезії над Сипілумом, не дозволяє стверджувати однозначно. Адже на монетах 138-276 рр. н.е. з однаковим оздобленням аверса та реверса у композиції показано як витікаючу воду9 , так і просто урну10.

Розуміння образу на монетах Тріполіса, як правило, полегшувала легенда TPIПO $\Lambda$ EIT $\Omega N$ MAIAN $\Delta \mathrm{POC}^{11}$, хоча трапляються і скорочені до TPIПO $\Lambda$ EIT $\Omega \mathrm{N}^{12}$ написи. Географічна локалізація й особливості течії річки лягли в основу трансформації образу річки. На монетах Тріполіса під назвою Аполонії доби імператорів Августа 13 та Тиберія головна річка регіону присутня у вигляді відповідного символу меандру.

Образ річкового бога Меандра був більш-менш сталим, а оздоблення лицьової сторони монети містили персоніфікації демосу, богині Роми, сенату. Такий набір символів був доволі типовим свідченням романізації регіону та поєднання суто грецьких образів пошани явищ грецької культури можна розцінювати як спробу віднайдення балансу під тиском римської культури. Монети з річковим богом Меандром карбувались як у напівавтономному карбуванні, так і від імені правителів імперії чи членів їх родин. Усі ці монети були виготовлені з бронзи та мали більш-менш уніфікований діаметр у межах 26-30 мм. Трапляються як менші варіанти з діаметром 24 мм, так і значно більші монети з діаметром 33 мм. Зменшення діаметра заготовки не завжди позначалося на якості малюнка чи детальністю легенди. Цікаво, що зазначення демосу чи сенату могло варіюватись від простого «HMOC»14 (вже із витікаючою водою) чи «СYNKАНTOC»15 до повної формули «HMOC TPIПO $\Lambda$ EIT $\Omega$ N» 16 чи «IEPA CYNK $\Lambda$ HTOC»17. У цьому ж зв'язку треба згада-

\footnotetext{
9 British Museum, Department of Coins and Medals, Catalogue of Greek Coins of Ionia (далі - ВМС). London: The Trustees, 1892, 20; Sylloge Nummorum Graecorum: The Royal Collection of Coins and Medals, Danish National Museum, 1942 (далі - SNG Cop), 248.

10 BMC 22.

11 Mionnet T. Description de Medailes antiques grecques et romaines (далі - Mionnet III (Caria)), Paris, 1806, III (Caria), 513.

12 BMC 25; Mannsperger D., Sylloge Nummorum Graecorum: Deutschland. Münzsammlung der Universität Tübingen: Heft 5. Karien und Lydien. Berlin, Gebrüger Mann, 1994 (далі - SNG Tuebingen) 3880.

13 Paris 1778.

14 BMC 27.

15 Mionnet III (Caria), 514; Paris 1776; Grose S. Catalogue of McClean Collection of Greek Coins. Fitzwilliam Museum. Vol. III (Asia Minor, Father Asia, Egipt, Africa). Cambridge, 1929, 8731.

16 BMC 16; SNG Cop 718 var (bust type); RPC III 2572.

17 BMC 35; Sylloge Nummorum Graecorum, Sammlung Hans von Aulock Vol. 1: Pontus, Paphlagonia, Bithynia, Mysia, Troas, Aiolis, Lesbos, Ionia. Berlin, 1957 (далі - SNG von Aulock) 3305, 8292; Sylloge
} 
ти і про цікавий випадок, коли персоніфікацію сенату уособлює жіноче погруддя 18 !

Більш офіційний характер носило карбування із зображеннями правителів. Вперше річковий Меандр з'явився на монетах Марка Аврелія19. Монети відзначались від вищезгаданих типів тільки оздобленням лицьової сторони, де вміщували портрет емітента та легенду. Такі монети містять портрети Фаустини II20, Юлії

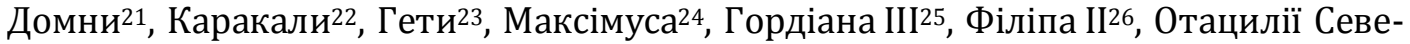
ри ${ }^{27}$, Гереннія Етруска 28.

Подібним чином розвивалося монетне карбування і в іншому карійському місті - Антіохії над Меандром. Спочатку значення великої річки на монетах II ст. до н.е. передавалось зображенням меандру, а на монетах Траяна ${ }^{29}$, Гети ${ }^{30}$ та Філіпа II 31 використане зображення та легенда, подібні до Тріполісу. У легенді, авжеж, міститься інша географічна прив'язка як MAIAN $\Delta$ POC ANTIO-XE $\Omega N$. На зворотному боці монет імператора Галлієна вміщено дуже складну і цікаву композицію про ріку Меандр та її бога. Там зображено міст над річкою з шістьома арками й огорожами. Ця конструкція є типовим акведуком (arched arcuatio). Наприкінці моста вміщено потрійний звід тріумфальної арки або якоїсь будівельно-технічної конструкції. Увінчує цю композицію зображення старшого чоловіка, що лежить на лівому боці та $є$ персоніфікацією річкового бога Меандра. Аналогічне оздоблення має і медальйон з Антіохії. Від попередньої монети медальйон відрізняється лише діаметром (37 мм) та чіткістю штампуз32.

Поодинокі випадки появи персоніфікації річкового бога Меандра трапляються і на інших монетах карійських міст - Еїппи (Еuippe) ${ }^{33}$ із зображенням Коммода ${ }^{34}$

Nummorum Graecorum, Schweiz II Münzen der Antike, Katalog der Sammlung Jean-Pierre Righetti im Bernischen Histirichen Museum, Berne 1993, (далі - SNG Righetti), 1113; Falter 529.

18 Paris 1778.

19 Babelon E. La collection Waddington au cabinet des médailles. R.N. Paris, 1897 (далі - Waddington), 2685; Sylloge Nummorum Graecorum Österreich, Sammlung Leypold, Kleinasiatische Münzen der Kaiserzeit, edd. W. Neustadt, W. Szaivert, C. Daburon. Vol. I, Vienna, 2002 (далі - Leypold I), 1339; Paris 1822.

20 BMC 63-66; SNG Cop 746; Imhoof-Blumer F. Fluss und Meergötter... 340; SNG von Aulock 3319-3320; Sylloge Nummorum Graecorum. The Lewis Collection in Corpus Christi College, Cambrige, ed. M.J. Price and I.A. Carraclice (далі - SNG Lewis), 1551.

21 Classical Numismatic Grupe (далі - CNG) 226, 450.

22 Paris 1991.652.

23 SNG von Aulock 3321; Paris 1826.

24 URL: http://www.wildwinds.com/coins/greece/lydia/tripolis/t.html

25 Boersema 14018.

26 SNG von Aulock 3324; Mionnet III (Caria), 537.

27 Lindgren H., Kovacs F. Ancient Bronze Coinage of Asia Minor and the Levant, Vol. I, San Mateo, 1985 (далі - Lindgren I), 854; Mionnet III (Caria), 536.

28 Mionnet III (Caria), 539; Mionnet Suppl. VI (Caria), 589; Paris 1840.

${ }^{29}$ Amandry M., Burnett A., Mairat J. Roman Provincial Coinage III, From Nerva to Hardian (AD 96-138), London, Paris, 2015, (далі - RPC III) 2241; Paris 149; Imhoof-Blumer F. Fluss und Meergötter... 285.

30 BMC 15-16.

31 BMC 50 var.

32 SNG von Aulock 8059.

33 Місцезнаходження полісу достеменно невідоме, локалізується в Карії між річками Марсій і Гарпас.

34 SNG von Aulock 2520; Roman Provincial Coinage Online. URL: http://rpc.ashmus.ox.ac.uk/ (далі RPC online), 888. 
та легендою MEAN $\triangle$ POC EYIППЕ $\Omega N$ і Тралл. Тралли, відомі під назвами Дія, Кесарея, Селевкія над Меандром, у своєму карбуванні здебільшого використовували символ меандру. Тим не менше, візерунок меандру вміщували навіть в оздоблення цистофорів ${ }^{35}$. У часи Адріана у Траллах карбується монета, так би мовити, «канонічного» типу із зображенням бога Меандра, який лежить на лівому боці, тримаючи тростину. Друга рука бога спирається на амфору, з якої витікає вода 36. Подібний «канонічний» тип зображення Меандра використано в оздобленні монет Галлієна ${ }^{37}$. 138-144 pр. н.е. датується монета із погруддям Марка Аврелія та зображенням річкового бога Меандра на звороті. Образ доповнює легенда магістрату та зображення юнака Евдонія (притоки Меандра) на колінах бога 38 .

Окремо слід сказати про карбування міста Магнезія над Меандром. Сама географічна прив'язка мала б сприяти появі персоніфікації річкового бога на монетах міста, однак $є$ лише одна монета із таким оздобленням. Для Магнезії притаманне було використання візерунку меандра у поєднанні із зображенням бика і лише у часи Марка Аврелія з'явилась доволі таки велика бронзова монета (діаметр 35 мм, вага - 25,22 г) із зображенням річкового бога. На реверсі зображено культову статую Артеміди Левкоприєни (Artemis Leukophryene, «Артеміда з білими бровами»), яку коронують дві Ніки, а сама статуя спирається на двох річкових богів 39.

Притокою Меандра була річка Лік. Персоніфікація цього річкового бога вміщена на монетах міст Фіатира (сучасний Акхісар) та Атталея. Монет із Фіатири $\epsilon$ доволі багато, оскільки в усі часи свого існування місто було важливим сировинним і торгівельним центром, яке спеціалізувалося передусім на фарбуванні одягу. Розташована на перетині торгівельних шляхів між Сардами, Пергамом та Ефесом, Фіатира потребувала значної грошової маси. Здебільшого Ліка зображали у «канонічному» типі на реверсі напівавтономних бронзових монет, що карбувались у різні часові проміжки упродовж 100-276 pр. н.е. На їх аверсі вміщували зображення різних грецьких божеств (Діоніса, Артеміди Бореітени (Boreitene, локальний епітет богині ${ }^{40}$ ), Тюхе) та сенату. Стосовно останнього, то цікаво, що $\epsilon$

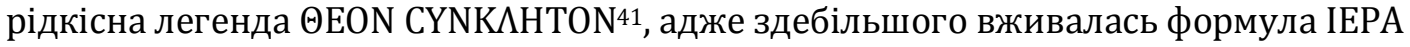
CYNK $\Lambda$ HTOC 42.

Із цікавих зразків карбування із персоніфікацією річкового бога Ліка з Фіатири слід згадати псевдоавтономні бронзові медальйони, датовані 222-235 pр. н.е. Це важкі, великі вироби вагою 35,07 г із персоніфікацією сенату на аверсі, а на реверсі вміщено композицію, коли бог Лік сидить, опершись на пагорб, із гілкою (не тростиною) у руці, спираючись на урну, з якої витікає вода. Бог ніби простя-

\footnotetext{
35 Noe, 5.

36 Helios Falter Coll., 526; Mionnet Supp. VII, 712; RPC III 2085.

37 BMC 195; Waddington 5463; Paris 1755.

${ }^{38}$ Imhoof-Blumer F. Fluss und Meergötter... 339; Imhoof-Blumer F. Beiträge zur Erklärung griechischer Münztypien // Nachtrag zu Nomisma. VI. 1911. № 4; Mionnet IV, 1086.

39 Schultz 111-112 var (rev. legend); Paris 1491 var (ditto).

${ }^{40}$ Jarzęcki K. Artemida w Antycznym Mennictwie Greckim / Artemis in Ancient Greek Coinage // Biuletyn Numizmatyczny. 2012. № 3.367. S. 168.

${ }^{41}$ SNG Righetti 1098; Imhoof Flüss and Meergötter 335; Mionnet IV, 881; Sylloge Nummorum Graecorum Deutschland, München Staatlische Münzsammlung. Part 23: Lydien. Ed. W. Leschhorn, Berlin. 1997. (далі - SNG Munich), 606.

42 Mionnet IV, 877; Paris 1433.
} 
гає руку до бика, який йде вправо, щоб напитись ${ }^{43}$. Саме цей бик і був, напевно, подібно до Борисфена, персоніфікацією бурхливої течії Ліка. Подібний сюжет 3'явився на монетах-медальйонах часів Александра Севера 44 та Каракали (із півмісяцем на плечах у Ліка) ${ }^{45}$. На монетах Юлії Домітициї з легендою ӨЕА $\Delta$ OMITIA річковий бог немає рогу достатку46. На реверсі монеті часів Луція Вера (161169 рр. н.е.) зображено Аполлона, який керує квадригою вліво, а під ногами коней розміщено постать річкового бога з тростиною, права рука якого на урні47. Більш «канонічне» зображення Ліка вміщено на бронзові монети Юлії Маммеї48 та Коммода 49 .

На напівавтономних монетах з Атталеї ми зустрічаємо «канонічне» зображення річкового бога Ліка (із заростями тростини біля ніг) у супроводі легенди ATTA $\Lambda$ EAT $\Omega$ N $\Lambda \mathrm{YKOC}^{50}$. Цей же образ вжито у монетах Юлії Домни та Коммода (правда, легенда АТTA $\Lambda$ EAT $\Omega N$ ). У Атталеї також викарбовано напівавтономну монету із зображенням Артеміди Бореітени (Boreitene), як і у Фіатирі, однак бог Лік показаний молодим юнаком з оголеним торсом¹.

Цікавий сюжет персоніфікації вміщено на монетах Лаодикеї над Ліком. Біля цього міста річки Капр і Лік зливались з Меандром ${ }^{52}$. На монетах з Юлією Домною річки Лік і Капр персоніфіковані як вовк - зліва та кабан - справа, які сидять по обидва боки у ніг Зевса53, а на монеті Філіпа II так само, тільки без Зевса54.

Однією з приток Меандра була сьогодні не існуюча річка Гіппурій. Вона протікала у каменистому каньйоні навколо міста Блаунд (Blaundos, Sülümenli villageUlubey-Uşak) на кордоні Лідії та Фригії. У карбуванні цього міста і є персоніфікація Гіппурія у поєднанні із обов'язковою назвою річки у легенді - IППОҮРІОС. Монети датуються здебільшого 240-260 рр. н.е. та носили автономне55, напівавтономне 56 та псевдоавтономне 57 карбування. На лицьовому боці монет, як правило, вміщувалась персоніфікація демосу із легендою $\Delta \mathrm{HMOC} B \Lambda \mathrm{AYN} \Delta \mathrm{E} \Omega \mathrm{N}$. Також персоніфікація Гіппурія вміщена на монеті Філіпа II. Важливим $є$ те, що «канонічний» образ персоніфікації у вигляді чоловіка, який лежить із рогом достатку та тростиною, доповнює зображення риб, що пірнають у потоках води, що ллється із урни ${ }^{58}$. Такий факт може свідчити про рибне багатство річки та значення рибальства у житті полісу. А ще на одному зразку карбування Філіпа I богиня Тюхе

\footnotetext{
43 Mionnet IV, 878.

${ }^{44}$ SNG von Aulock 3235.

${ }^{45}$ SNG von Aulock 8278.

46 Paris AA.GR.853.

47 URL: http://www.wildwinds.com/coins/greece/lydia/thyateira/t.html

48 BMC 135.

${ }^{49}$ Mionnet Supp. VII, 608; Paris 1479.

50 URL: http://www.wildwinds.com/coins/greece/lydia/attaleia/t.html

51 Imhoof: Flüss and Meergötter 302; Sylloge Nummorum Graecorum Great Britain, Vol. IV, Fitzwilliam Museum, Leake and General Collections, Part 7: Asia Minor: Lycia-Cappadocia. London, 1967. (далі SNG Fitz) 4846.

52 Страбон, Географія, XII, VIII, 16.

53 BMC 215.

${ }^{54}$ SNG Cop 607; Weber 7151; Paris 1640.

55 SNG Lewis 1522.

56 SNG von Aulock 2923, SNG Fitzwilliam 4850; Mionnet IV,107.

57 BMC 53.

58 Imhoof-Blumer F. Fluss und Meergötter... 306 var (rev. legend); SNG von Aulock 2930 var (ditto); BMC 87 var (ditto).
} 
сидить на троні зі скіпетром у руці над зображенням річкового бога, ліва рука якого покладена на голову, а права - на урну59.

Поруч із Меандром протікала річка Каїстр, тепер відома під назвою Кӥс̧ӥk Menderes (тобто Малий Меандр). Річка бере початок біля гори Тмол, протікаючи по Лідії та Іонії, впадає у море біля Ефесу. Рівнина Каїстра була надзвичайно родючою, а у верхів'ях Каїстра протікала притока Кільб. Цю частину називали Кільбіанською60. Довжина Каїстру в теперішній час складає 114 км, площа басейну 3502 кв. км. На цій території було розташовано кілька міст, які у своєму карбуванні не могли оминути увагою постать річкового бога Каїстра. Перше місце серед них посідає карбування міста Дієс Гієрон (Діосполіс) у верхів'ях Каїстра. Це маленьке містечко було розташоване між Лебедосом і Колофоном, біля сучасного Birgi у Туреччині. Тут монети із персоніфікацією річкового бога Каїстра випускались в автономному та напівавтономному карбуванні. На аверсі автономних монет вміщено персоніфікацію сенату та доволі рідкісну персоніфікацію демосу. Такі монети карбувались у 100-200 рр. н.е., на аверсі вміщено жіноче погруддя у короні з легендою ПОАІС. На зворотному боці монети вміщено «канонічне» зображення річкового бога, який лежить на лівому боці із рогом достатку та тростиною, спираючись на урну, з якої тече вода і легенда $\Delta \mathrm{IOCIEPEIT \Omega N.61} \mathrm{На} \mathrm{монетах}$ 138-192 pр. н.е. вміщено персоніфікацію сенату з легендою CYNKАHTOC IEPA і персоніфікацію бога Каїстра з легендою $\triangle \mathrm{IOCIEPEIT \Omega N} \mathrm{KAYCTPOC} \mathrm{у} \mathrm{«канонічному»}$ зображенні із витікаючою водою62.

У напівавтономному карбуванні Дієс Гієрона Каїстр з легендою $\Delta \mathrm{IOCIEPEIT \Omega N}$ КАҮСТРОС представлений на монетах із персоніфікацією демосу63. На відміну від автономного карбування, тут демос, як належить, позначений чоловічим погруддям з бородою.

Однією з приток Каїстра була річка Кільб (КІ $\Lambda$ ВОС). Персоніфікацію цього річкового бога ми можемо побачити на монетах міста Нікея-Кільбіані у Лідії. Випуски монет датуються часами Антоніна Пія, Коммода, Каракали, Гети, Юлії Домни. У легенді, як правило, застосовується формула KI $\Lambda$ BI T $\Omega N$ AN $\Omega$ KI $\Lambda$ BOC чи NEIKAE $\Omega N$ KI $\Lambda$ BIAN $\Omega N$. Ймовірно статус притоки підкреслено зображенням річкового бога як молодого юнака. Права рука його лежить на колінах, адже він не може бути батьком Каламоса, який перетворився на тростину. На монетах Антоніна Пія64 та Коммода65, Каракали 66 , річковий бог не має рогу достатку, а тільки тростину. На монетах Юлії Домни ${ }^{67}$ персоніфікація річкового бога супроводжує поширення образу божественності цієї жінки (IOYАIA CEBACTH).

\footnotetext{
59 Falter Coll. 447.

60 Любкер Ф. Реальный словарь классических древностей... $\quad$ C. $266 . \quad$ URL: https://dlib.rsl.ru/viewer/01003599381\#?page=147

61 Paris 275; Vienna 34916; Sylloge Nummorum Graecorum, Turkey 5: Tire Museum (Izmir), Vol. 1: Roman Provincial Coins From Ionia, Lydia, Phrygia, etc. Istanbul, 2011 (далі - SNG Turkey 5), 342; Sylloge Nummorum Graecorum, Turkey VII, Odemis Museum, Vol. 1: Roman Provincial Coins of Ionia, Lydia and etc., Istanbul, 2012. (далі - SNG Turkey 7), 200-201.

62 Imhoof-Blumer F. Fluss und Meergötter... 308; SNG Turkey 5, 345; SNG Turkey 7, 209.

63 Bаріант BMC 4; Mionnet IV, 181.

${ }^{64}$ RPC online, 1212, Imhoof-Blumer F. Fluss und Meergötter... 315.

65 Paris M6593.

${ }^{66}$ SNG von Aulock 2993 corr.; Kowalewski P. Flussgötter und ihre Attribute... P. 7, fig. 14. Mionnet

Supp. 7, 109.

67 SNG Münich 211; BMC 13.
} 
Говорячи про притоки Каїстра, слід сказати про персоніфікацію притоки Астрай (Astraios, сучасна назва Çevlik). Цей образ закріплений у карбуванні міста Метрополіс в Іонії часів Александра Севера68, Максімуса ${ }^{69}$, Гордіана III70 та Філіпа II71. Образ річкового бога є доволі типовим, за винятком тільки того, що на монеті Філіпа II немає рогу достатку.

Наступною великою річкою західного узбережжя Малої Азії була річка Герм ('E $\rho \mu$ s, Hermus (Hermos), сучасна назва Gediz Nehri). Довжина ріки у теперішньому часі становить 341 км, а басейн - 17500 кв. км. Згадка про Герм $\epsilon$ ще в «Іліаді» Гомера (XX, 393). Ця річка мала свого річкового бога, сина Океана і Тефіди, який був батьком лідійських німф. Як вже зазначалось, Герм відділяв Еолію від Іонії, включаючи Іонійську Фокею на півночі. У басейні Герма були розташовані такі лідійські міста як Табала, Магнезія над Сипілумом, Саїтта, Сіланд, Багіс, Мостена, Сарди тощо. Усі вони були важливими центрами ремесла та торгівлі. В їхньому карбуванні активно використовувалась персоніфікація річкового бога. Здебільшого це була «канонічна» композиція, коли бог лежить на боці, з тростиною у правій руці, а ліва рука спирається на урну, з якої тече вода.

У залежності від міста-емітента, легенда містила відповідний етнікон $\left(T A B A \Lambda E \Omega N\right.$ EPMOC72, ВАГНN $\Omega N$ EPMOC73, EПI CTA ATTA ${ }^{72}$ IANOY EPMOC74, CAP $\triangle I A N \Omega N$ B NE $\Omega K O P \underline{W}$ EPMOC75, CAITTHN $\Omega N$ EPMOC76, МАГNHT $\Omega N$ CIПY $\Lambda O Y$ EPMOC77, MOCTHN $\Omega N$ EPMOC). Відповідні монети карбувались як автономно, так і напівавтономно чи псевдоавтономно. На аверсі монет із персоніфікацією річкового бога Герма вміщувались зображення буле, сенату, демосу, а також місцевих божеств-покровителів. Датуються такі монети здебільшого 40-ми роками III ст. н.е.

Відомі також імператорські карбування з погруддями Юлї̈ Маммеї як Себасти. Таким чином її вшанували мешканці міст Табала78, Саїтта79, Сарди ${ }^{80}$. Божественність Фаустини II81, Криспіни ${ }^{82}$, Доміції Лонгіни ${ }^{83}$, Сабіни ${ }^{84}$ вшанували Сарди. Монети з погруддям Галієна викарбувані у Саїтті85, Гордіана та Транквіліни - у Табалі86.

Тим не менше, були і варіації композиції. Цікавим зразком передусім є невелика бронзова монета (12 мм, 1,39 г) навпівавтономного карбування з Магнезії,

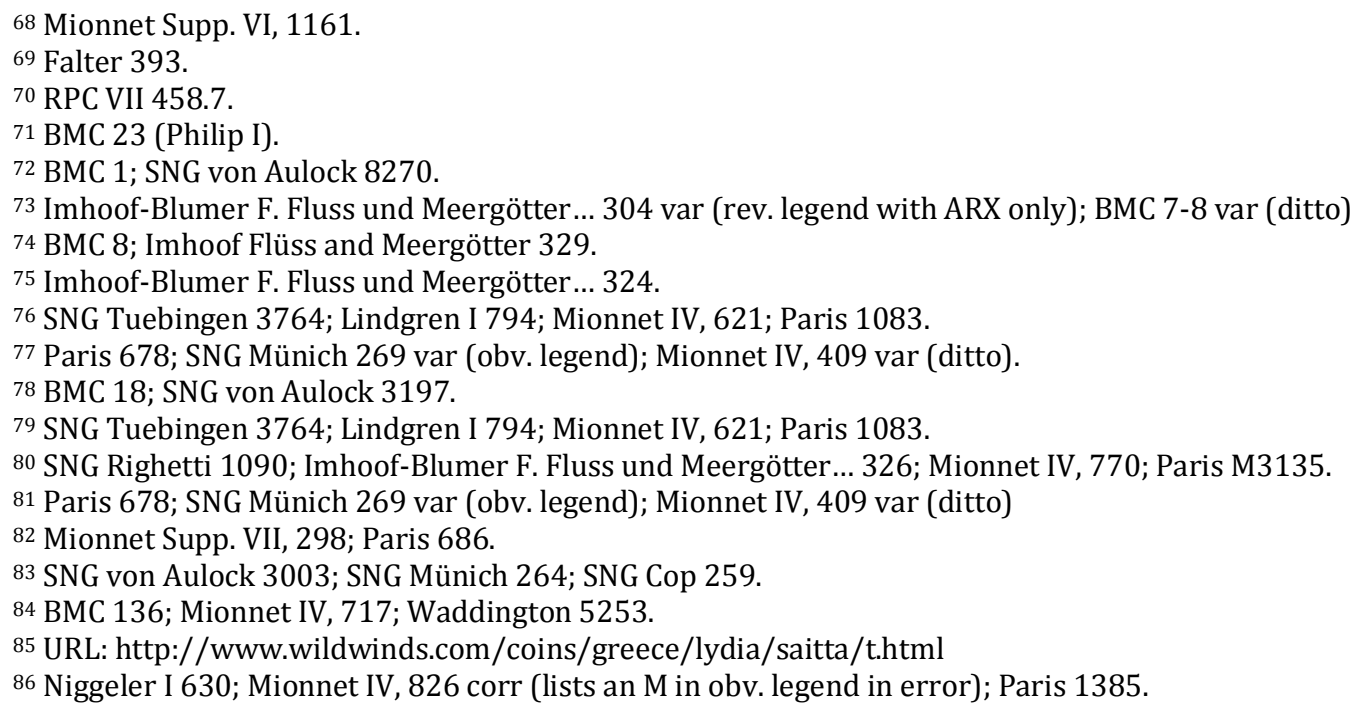


коли річковий бог Герм прикрасив лицьовий бік монети. На звороті вміщено ле-

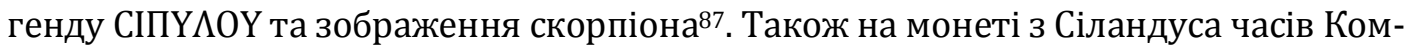
мода композиція сидячого річкового бога Герма доповнена зображенням оголеної до поясу німфи, що стоїть навпроти й обнімає дерево 88 . На звороті монети 3 Сард вміщено композицію з двох частин: оголений Тріптолем у хламиді керує вправо колісницею, запряженою двома крилатими зміями, у правій руці Триптолема калаф і він висіває насіння. Під колісницею розміщено постять лежачого річкового бога ${ }^{89}$. Легенда про Тріптолема, його землеробське спрямування та той факт, що на монеті з Багей річковий бог тримає у руці тростину та колосся90, дозволяє переглянути версію про тростину у руці як атрибут усіх річкових богів. Так, у випадку Меандра, за міфічною історією якого бог мав сина, що став тростиною, це є абсолютно достовірним. Але можна піднімати питання, що нечіткість штампу й активне використання розмінної монети з персоніфікацією інших річкових богів спотворює вигляд предмета в руці богів усіх інших річок, який можна вважати колоссям. Тим більше, що на монетах Галлієна з Ієрополіса-Кастабали у Кілікії богиня Тихе, сидячи на троні над річковим богом Пірамусом, тримає у руці колосся 91 , а на монетах Антоніна Пія з Пауталії у Фракії92 три річкові німфи теж тримають колосся, а не тростину в руках. Таким чином, зважаючи на значення землеробства в долинах великих річок, цілком раціональним було підкреслення цього факту в оздобленні монет.

Тема приток Герма знайшла відображення у композиції оздоблення бронзової монети Сард із погруддям Гордіана III (238-244 pp. н.е.). На реверсі монети зображено річкового бога Герма з високо піднятим вінком у правій руці. На правому стегні бога сидить немовля Пактол 93 (притока Герма, сучасна назва Sart Çayı)94. На реверсі монети із Саїтти із погруддям Філіпа I (244-249) боги Гіл (притока Герма) та Герм сидять один навпроти іншого, кожен спирається на урну, з якої витікає вода. Над ними вміщено сидячу вліво постать німфи, що тримає в руці тростину95. В аналогічних композиціях з трьох постатей у карбуванні Саїтти, між Гілом і Гермом також уміщували Мена на п’єдесталі96 (погруддя Каракали на аверci) чи Мена у фрігійському вбранні та з шишкою і скіпетром у руках ${ }^{97}$ (погруддя

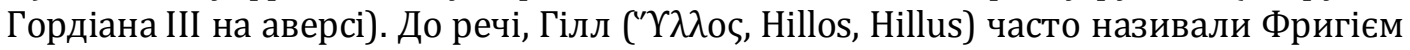
(Phrygius).

\footnotetext{
87 BMC 32; Mionnet Supp. VII, 265.

88 Imhoof-Blumen F. Nymphen und Chariten auf griechischen Münzen. Berlin, 1908; 474; BMC 23; Imhoof-Blumer F. Fluss und Meergötter... 331.

${ }^{89}$ Mionnet IV, 789; Paris 1313A.

90 BMC 9; SNG von Aulock 2914; Imhoof-Blumer F. Fluss und Meergötter... 303; Mionnet IV, 82; Falter 443.

${ }^{91}$ Levante, E. Sylloge Nummorum Graecorum, Switzerland I. Levante-Cilicia. Zurich, 1986, 1599; Sylloge Nummorum Graecorum, France, Bibliothéque Nationale, Cabinet des Médailles, Vol. 5: Mysia. Paris, 2001. 2247, Sylloge Nummorum Graecorum, Deutschland: Pfälzer Privatsammlungen, Part 4: Pamphylien, Munich, 1993, 602.

92 Imhoof-Blumer F. Nymphen... 498.

93 Пактол вважали золотоносною річкою (Геродот, 5, 101), причиною заможності Креза та його попередників (Стратон, Географія, XIII, С. 626) і Сард загалом.

${ }_{94}$ SNG von Aulock 3163.

95 Imhoof-Blumer F. Nymphen... 464.

96 BMC 46; Imhoof-Blumer F. Fluss und Meergötter... 323; Waddington 5182.

97 BMC 58; Mionnet IV, 622 corr. (rev. legend); Paris 1086.
} 
Наостанок слід сказати про одиничну, але тим не менш важливу монету з Пергама, яку вважають меморативною, про інавгурацію Мадрагського акведука між річками Селін і Цетей. Подія мала місце у часи Марка Арелія і, ймовірно, відображена у творі Елія Аристида. На реверсі монети показано сам акведук і постать Асклепія (як одного із символів Пергама) та річкових богів по боках. На думку дослідників ці постаті богів позначали межі акведука.

Таким чином, аналіз нумізматичного матеріалу дозволяє зробити певні висновки передусім про те, що у монетному карбуванні доволі таки скоро сформувався спосіб персоніфікації річок та їх богів. Незважаючи на те, що такі образи використовувались у карбуванні дрібної розмінної монети, саме їх чисельність і поширеність впливала на підтримку та закріплення місцевої духовної традиції.

Наявність спільних рис і сталого образу, умовно названого «канонічним», дозволяє припустити про існування усталеного штампу, яким користувались монетні двори міст провінції Азія. Цей штамп доповнювався лише індивідуальними легендами чи істотними для регіону особливостями.

Монети із персоніфікацією річкових богів дозволяють простежити певні особливості й у системі водопостачання регіону. Наявність кількох великих річок не могла не відобразитись у карбуванні, але, що цікаво, такі монетні типи з'являються у II-III ст. н.е. і пов'язуються із автономним чи напівавтономним карбуванням.

Монети із персоніфікацією річок поєднують у собі персоніфікацію таких важливих політично-абстрактних понять як демос, поліс, сенат, буле. Вкрай рідким було використання персоніфікації богині Роми. Можна припускати, що такі образи були способом відмежування від тиску традиційно римських цінностей у повсякденному житті населення провінції.

Також можна говорити про те, що для карбування певних імператорів притаманне використання образу річкових богів. До цієї теми найчастіше звертались у часи правління Гети, Коммода, Філіпа II, Юлії Домни, Юлії Маммеї, Гордіана III, рідше - у часи Каракалли й Александра Севера. Видається, що на чисельність монетних типів не впливало географічне розташування поблизу річки, а визначальним фактором було значення міста у провінційному ринку та потреба в обігових розмінних коштах. Саме цим пояснюються поодинокі випадки карбування монет з річковими богами у випадку одних міст (Атталея, Ніса, Герме, Магнезія над Сипілумом тощо) і кілька тиражованих образів у випадку інших (Фіатира, Нікея-Кільбіані, Блаунд, Тріполіс, Тралли, Діос Гієрон).

Перегляд усталених у нумізматиці образів на прикладі запропонованих зразків дозволяє поставити питання про значення символів і предметів, які супроводжували зображення річкових богів. Отже, тема річкових богів у нумізматиці дозволяє простежити низку важливих особливостей господарського та духовного життя регіону, а також частково відновити і суттєво доповнити гідрографічну ситуацію того часу у порівнянні з теперішньою.

\section{REFERENCES}

Amandry, M., Burnett, A. \& Mairat, J. (2015). Roman Provincial Coinage III. From Nerva to Hardian (AD 96-138). London, Paris.

Aulock, H. von \& Kleiner, G. (1957). Sylloge Nummorum Graecorum. Vol. 1: Pontus, Paphlagonia, Bithynia, Mysia, Troas, Aiolis, Lesbos, Ionia. Berlin.

Babelon, E. (1892). La collection Waddington au cabinet des médailles. R.N. Paris. 
Breitenstein, N. \& Schwabacher, W. (Eds.) (1942). Sylloge Nummorum Graecorum. The Royal Collection of Coins and Medals, Danish National Museum. Copenhagen.

Fitzwilliam Museum (1967). Sylloge Nummorum Graecorum. Great Britain. Vol. IV. Part 7: Asia Minor: Lycia-Cappadocia. London: Oxford University Press.

Grose, S. (1929). Catalogue of McClean Collection of Greek Coins. Fitzwilliam Museum. Vol. III: Asia Minor, Father Asia, Egipt, Africa. Cambridge.

Imhoof-Blumen, F. (1908). Nymphen und Chariten auf griechischen Münzen. Berlin.

Imhoof-Blumer, F. (1910). Beiträge zur Erklärung griechischer Münztypien. Zeitschrift für Numismatik, 6, 1-23.

Imhoof-Blumer, F. (1924). Fluss- und Meergötter auf griechischen und römischen Münzen (Personifikationen der Gewässer). Genève: Soc. École d'Horlogerie.

Jarzęcki, K. (2012). Artemida w Antycznym Mennictwie Greckim [Artemis in Ancient Greek Coinage]. Biuletyn Numizmatyczny, 3.367, 161-172.

Kapossy, B. \& Righetti, J.-P. (1993). Sylloge Nummorum Graecorum. Schweiz II. Münzen der Antike. Katalog der Sammlung im Bernischen Histirichen Museum. Berne: Haupt.

Karyshkovskiy, P.O. (1988). Monety Olvii: Ocherk denezhnogo obrashenia Severo-Zapadnogo Prichernomoria $v$ antichnuyu epohu [Coins of Olbia. Essay monetary North-Western Black Sea in Ancient Times]. Kiev [in Russian]

Kowalewski, P. (2006). Flussgötter und ihre Attribute auf antiken Münzen. In Wiplinger, G. Cura Aquarum in Ephesus. Leuven: Peeters, pp. 3-16.

Kremydi-Siciliano, S. (2005). Belonging to Rome, remaining Greek: coinage and identity in Roman Macedonia. In Howgego, Ch., Heuchert, V., \& Burnett, A. Coinage and Identity in the Roman Provinces. Oxford. DOI: 10.1093/oso/9780199265268.003.0012

Leschhorn, W. (Ed.) (1997). Sylloge Nummorum Graecorum. Deutschland, München Staatlische Münzsammlung. Part 23: Lydien. Berlin.

Levante, E. (1986). Sylloge Nummorum Graecorum. Switzerland I: Levante-Cilicia. Berne.

Levante, E. (2001). Sylloge Nummorum Graecorum. France, Bibliothéque Nationale, Cabinet des Médailles. Vol. 5: Mysia. Paris.

Lindgren, H. \& Kovacs, F. (1985). Ancient Bronze Coinage of Asia Minor and the Levant, Vol. I, San Mateo.

Mannsperger, D. (1994). Sylloge Nummorum Graecorum: Deutschland. Münzsammlung der Universität Tübingen: Heft 5. Karien und Lydien. Berlin, Gebrüger Mann.

Mionnet, T. (1806). Description de Medailes antiques grecques et romaines. Paris, III (Caria).

Neustadt, W., Szaivert, W. \& Daburon, C. (Eds.) (2002). Sylloge Nummorum Graecorum. Österreich, Sammlung Leypold, Kleinasiatische Münzen der Kaiserzeit. Vol. I. Vienna.

Nollé, J. (1993). Sylloge Nummorum Graecorum. Deutschland: Pfälzer Privatsammlungen. Part 4: Pamphylien. München.

Poole, R.S. \& Head, B.V. (1892). British Museum. Department of Coins and Medals: Catalogue of Greek Coins of Ionia. London: The Trustees.

Price, M.J. \& Carraclice, I.A. (1972). Sylloge Nummorum Graecorum. The Lewis Collection in Corpus Christi College. Cambridge, Oxford.

Tekin, Oğuz (2011). Sylloge Nummorum Graecorum. Turkey 5: Tire Museum (Izmir), Vol. 1: Roman Provincial Coins From Ionia, Lydia, Phrygia, etc. Istanbul.

Tekin, Oğuz (2012). Sylloge Nummorum Graecorum. Turkey 7: Odemis Museum, Vol. 1: Roman Provincial Coins of Ionia, Lydia and etc., Istanbul.

\section{Anastasia Baukova}

(Ivan Franko Lviv National University, Lviv, Ukraine)

e-mail: anastasia_bau@ukr.net

ORCID: https://orcid.org/0000-0002-1636-981X

\section{Personification of River Gods in Coinage of Roman Province of Asia}

Coins are an excellent source for studying various aspects of the history and culture of antiquity. The limited area of the metal disk did not affect the sense load of the image laid by the issuer. Coins, besides being a means of payment, played a very important role in perpetuating 
important and topical social changes and cultural and religious phenomena. For the cities of the former kingdom of Pergamum, the establishing of the Roman province of Asia was a great challenge, because, through the types of coins, Greek officials continued to preserve their identity. One of such tasks was to preserve traditional religious beliefs.

The personifications of river gods, symbolizing the major rivers of western Asia Minor, are analyzed in the paper. First of all, the Meander, Kaystros, Hermus, and their numerous tributaries are mentioned. These mighty rivers played not only a transport role and were a source of drinking water and food, but they also played the role of natural boundaries between the historical regions of Asia Minor. However, in everyday culture, their importance has not been emphasized for some time. But the population watched the rivers, and, for example, it was the regime of the Meander that gave the name to the symbol that is still used under this name. The relationship between the inhabitants of the valley and the Meander was so dynamic and unpredictable that the river was even sued.

Until a certain time, the personification of the largest river in the region on the coins of the river valley cities was observed in the form of a meander symbol. Coinage with personifications makes it possible to recreate the hydrographic situation in the region and the role of those rivers in the economy, because at present some waterways have changed their course or have just disappeared.

The paper also raises the question of the need to reconsider certain interpretations of the symbols, including urns with running out water or the cane in the hands of the river god.

Analysis of numismatic sources indicates that a unified way of river gods personification was quickly formed in the province, but the widespread use of river gods images began to be used in the coinage of provincial cities in the second half of the $2^{\text {nd }}-$ first half of the $3^{\text {rd }}$ century CE. Moreover, such emissions were of both autonomous and semi-autonomous character. Images of river gods also appeared on the coins with porters of emperors or women from imperial families among which whom Julia Domna, Julia Mammeia, Faustina II, etc.

An interesting feature is also pointed out when cities within easy reach of rivers did not give preference to the use of personifications, and the determining factor was the importance of the city in the provincial market and the need for money of exchange circulation. The analysis of legends also gives the opportunity to find out certain epithets and local features of allGreek deities.

Keywords: personification, river gods, Roman province of Asia, coinage 